\title{
ITALIANOS E O MOVIMENTO OPERÁRIO EM PORTO ALEGRE
}

Stella Borges ${ }^{1}$

Este artigo é na realidade uma adaptação do tema de minha dissertação de mestrado, defendida em 1990 na Pontifícia Universidade Católica do RS, posteriormente publicada sob o título Italianos: Porto Alegre e Trabalho (Borges, 1993) e que teve na ocasião o objetivo de contrapor a situação do trabalhador italiano urbano em São Paulo e em Porto Alegre. Desde lá, meu interesse tem sido a questão da identidade étnica entre os imigrantes italianos, estudando o caso de Santa Vitória do Palmar.

Outras abordagens sobre o tema vem sendo trabalhadas, isto é, sobre a questão do trabalhador italiano na República Velha e suas relações com o trabalho, seja como alienado no Hospício São Pedro ou como encarcerado na Casa de Correção (Borges \& Costa, 1996, p. 406-423).

O final do século XIX, corresponde no RS a um período extremamente efervescente; a penetração tardia do capitalismo é acompanhada de diversas transformações como o processo de abolição da escravidão, o trabalho assalariado, a vinda de imigrantes europeus, especialmente italianos, o processo de industrialização e conseqüente

1 Professora de História do Brasil e RS, Mestre e Especialista em História do Brasil pela Pontifícia Universidade Católica do RS - Porto Alegre, Aperfeiçoamento em Ciência Política pelo Istituto di Studi Storici - Facolta di Scienze Politiche da Universidade de Padova/Itália, docente da Universidade Luterana do Brasil (ULBRA). 
urbanização, a emergência de novas classes sociais como uma burguesia incipiente e o nascente proletariado.

Neste período começam a surgir as primeiras movimentações operárias no RS. Politicamente o RS é governado pelo PRR, Partido Republicano Rio-Grandense que se tornou hegemônico a partir da proclamação da República e da Constituição Positivista; Júlio de Castilhos está no poder.

A maioria dos imigrantes italianos vão se organizar nas mais diversas formas de agremiaçōes, em busca de melhores condições de trabalho, de salários etc. juntamente com outros grupos proletários ou em processo de marginalização, “(...) em uma sociedade recém-saída da escravidão, a organização operária aparece como o primeiro movimento social das camadas dominadas voltado por seus objetivos manifestos, modelos ideológicos, métodos de ação, para a mudança de aspectos básicos da estrutura de poder” (Fausto, 1977, p. 122).

\section{Trabalhadores italianos na República Velha}

No Rio Grande do Sul, sob forte influência positivista, as transformações advindas do processo de industrialização, a falta de legislação, o modo de encarar as questóes sociais como um caso de polícia, fizeram com que o proletariado, também aqui, sofresse todo o tipo de exploração. O descaso por parte dos governantes provocou uma reação do operariado que passou a se organizar em associações e sindicatos a fim de obter melhores condições de trabalho. Mobilizados, principalmente através de movimentos paredistas, muitas vezes conseguiram que os patrôes cedessem.

Ao lado da política de importação de braços estrangeiros, a política estadual, neste período, através do Partido Republicano RioGrandense (PRR), além de encarnar a idéia de progresso via teoria positivista, respondia aos anseios do momento, especialmente no que diz respeito à modernização econômica, pois os interesses de diversos grupos convergiam. O positivismo vinha ao encontro dos interesses do grupo burguês ascendente que passa a reinvestir na indústria nascente, bem como das camadas sociais emergentes, incluindo-se, aí, o imigrante urbano. 
Com o crescimento do comércio e o gradual desenvolvimento da indústria, grande contingente foi responsável pela prática do ideal de progresso positivista. De um lado, o capital dos novos grupos, aliado a uma política favorável; de outro, os trabalhadores e operários assalariados, que dispõem do trabalho e da possibilidade de organização. $\mathrm{O}$ PRR pretendia, quando muito, conceder apenas alguns direitos sociais. Politicamente, a atuação do PRR, pautou-se no progresso e desenvolvimento de variadas atividades econômicas.

No processo de formação do proletariado gaúcho várias tendências atuaram: socialistas, anarquistas e anarco-sindicalistas, que tinham concepções diferentes no encaminhamento das reivindicações, apesar de convergirem em alguns pontos (Petersen, 1980, p. 288-89).

\section{Movimento operário em Porto Alegre}

A história do movimento operário no Rio Grande do Sul pode ser dividida em três etapas. O período Mutualista que seria a fase embrionária do sindicalismo gaúcho e começaria com a fundação da Sociedade Operária de Mútuo Socorro e Beneficência Vitorio Emanuelle (sic). Entretanto, sabe-se que as sociedades de mútuo socorro italianas não evoluíram para o sindicato, e a Sociedade Vitorio Emanuelle II nunca foi uma sociedade operária e sim da elite italiana da capital. Tal período vai de 1877 até 1892 . A segunda etapa correspondeu ao período Social-Democrata, que teria sido “(...) embebido ideologicamente na social democracia alemã (...)", este período começaria com a fundação da "União do Trabalho", em Rio Grande, no ano de 1892 , e iria até 1910 . Finalmente, o período Anarquista, que começaria com a tomada da Federação Operária do Rio Grande do Sul (FORGS) pelos anarquistas, e que se estendeu até 1930 (Marçal, 1985, p. 13-4).

Os imigrantes italianos, trabalharam em número reduzido nas indústrias, sendo a maior parte da mão-de-obra empregada neste setor composta por elementos de outras etnias. O contingente de força de trabalho dos imigrantes italianos se distribuiu especialmente no pequeno e médio comércio.

As primeiras manifestações reivindicatórias no Rio Grande do Sul surgiram no final do século passado. O primeiro grupo socialista em Porto Alegre surge em 1891, com a participação de "jovens ope- 
rários" como Francisco Xavier da Costa, Otaviano de Oliveira, Lucídio Marinho Prestes, João Martirema, Pedro Tácito Pires e outros, sendo dois imigrantes alemães (Marçal, s/d, p. 11).

A mobilização em torno da organização de um partido foi aumentando. Em 1892 (L'Avvenire, 7.3.1892), realizou-se no salão do Teatro São Pedro uma reunião com operários de diversas nacionalidades. Compareceram cerca de 200 pessoas e, como representante dos operários italianos, discursou Colombo Leoni, ex-membro da Colônia Cecília e diretor do jornal L'Avvenire. Paradoxalmente, Colombo Leoni, de origem libertária, falou da necessidade de "...fundar um partido para organizar os meios de defesa contra a miséria”; após seu discurso em português, discursou em italiano, dirigindo a palavra aos seus conacionais, convidando-os a participarem. Octavio Giacomuzzi reforçou o pedido de Leoni, estimulando a formação de um partido.

Em 1894 (Rodrigues, 1984, p. 57), foi fundado o Grupo dos Homens Livres de Porto Alegre. Neste grupo se encontravam, entre outros, Giovanni Rossi e Gigi Damiani, que fundaram o jornal A Luta, de tendência anarquista, sob a direção do médico Frederico Geyer.

A Liga Operária Internacional, presidida por Francisco Xavier da Costa, que era gráfico, foi fundada em novembro de 1895, enquanto o grupo socialista de alemães já havia fundado o Allgemeiner Arbeiterverein.

Após a propagação da idéia socialista no Estado, surge em 1897 o Partido Socialista Rio-Grandense. A presença de imigrantes europeus é bastante expressiva, especialmente alemäes, seguidos por italianos.

Em maio de 1897 (Gazetinha, 20.5.1897), há uma eleição do diretório. O início dos trabalhos foi presidido por José Ferla. Participaram ainda os italianos José Vitola e Carlos Dell'Appa.

Os socialistas organizaram o Primeiro Congresso Operário realizado no Rio Grande do Sul, em janeiro de 1898, tendo como representantes italianos: a Sociedade Tipográfica Rio-Grandense com Giuseppe Ferla; Grupo Libertário, com Giuseppe Vitola e Caetano Seventi; União Construtora, com José Andre Setta; Liga Operária Internacional de São Leopoldo, com José Stringuini, e a Liga Operária de Pelotas com João Thomas Mignone (Gazetinha, dez. 1897/jan. 1898).

Neste Congresso Operário, Giuseppe Ferla dirigiu os trabalhos; entre os eleitos para fazer o resumo das propostas apresentadas esta- 
vam Giuseppe Vitola e o próprio Ferla. Dentre as propostas apresentadas havia a criação de ligas operárias internacionais, a criação de bibliotecas e a fundação de um jornal socialista.

Como conseqüência da disseminação da idéia socialista, principalmente a partir do $1^{\circ}$ Congresso, vários grupos socialistas no interior do estado reúnem-se, como por exemplo em Rio Grande, onde havia expressiva colônia italiana. Em carta escrita ao Jornal Social (23.4.1899) de Alegrete, Guedes Coutinho relata a situação política em Rio Grande; alega a falta de consciência do operariado e o considera "como uma manada de ovelhas". Noticia ainda uma reunião do Partido Socialista realizada em 26.2.1899 nos salões da União Operária. A conferência teve como orador Ricardo Doni e foi, segundo o jornal, toda ela em idioma italiano, pois a maior parte da platéia era composta por operários italianos.

O nível de organização do movimento operário do início do século era bastante significativo, como se vê pelo fato de que em congresso realizado em 1902 para a constituição do Partido Socialista, em São Paulo, "participaram 45 delegados (28 dos quais italianos, 13 brasileiros, 2 espanhóis e 2 alemães), representando 42 organizações" (Trento, 1989, p. 225), onde o Rio Grande do Sul esteve representado por duas organizações.

"Depois de São Paulo, era no Rio Grande do Sul, porém, que a tendência socialista do movimento operário estava mais expandida, havendo núcleos em várias cidades" (Hardmann, 1982, p. 250).

Em 1905, surge o Partido Operário Rio-grandense. Uma comissão provisória do Partido lança. um manifesto (A Democracia, 1.5.1905, p. 2-3), onde escrevem sobre os presos e citam o caso do operário italiano De Vivo, que esteve detido, pois teve a "incrível audácia” de querer castigar fisicamente o patrão. No manifesto há também a constatação da falta de representantes operários em diversos setores sociais.

O $2^{\circ}$ Congresso Operário do Rio Grande do Sul, programado para 1909, em Porto Alegre, não se realizou (Correio do Povo, 5.5.1909, p. 1). Somente em 1920 foi possível realizar o mesmo.

Entre o primeiro e o segundo Congresso, muitas experiências foram acumuladas; greves em busca de melhorias de trabalho, muitas delas vitoriosas; a produção industrial havia aumentado, a Federação Operária havia sido fundada, enfim, o proletariado tinha agora experiências próprias de luta. Em termos mundiais, dois acontecimentos 
tiveram repercussão quase que imediata no Brasil e também em Porto Alegre: a $1^{\mathrm{a}}$ Guerra Mundial e a Revolução Russa.

No $2^{\circ}$ Congresso realizado em Porto Alegre, diversos assuntos foram debatidos: a organização do movimento, a jornada de 8 horas de trabalho, a questão dos deportados etc. Entre as 18 delegações representadas no Congresso havia representantes italianos: Adão Lucetilli, do Sindicato de Ofícios Vários de Caxias; Carlos Toffolo, do Sindicato dos Metalúrgicos de Porto Alegre; Luiz Derivi, o representante de O Sindicalista e da FORGS, perfazendo 16,6\% (Rodrigues, 1969 , p. 40).

Em 1925, foi realizado o $3^{\circ}$ Congresso Operário do Rio Grande do Sul. Neste evento estavam presentes vários delegados da capital e do interior. Somente 2 representantes eram de origem italiana: o representante do Comitê Pró-Presos de Porto Alegre, Francisco Grecco, e o representante do Sindicato Padeiral de Santa Maria, Sebastião Lamotte (Rodrigues, 1969, p. 48).

Este Congresso se constituiu de doze reuniões onde foram discutidos diversos aspectos da organização operária: imprensa, trabalhadores rurais, situação da mulher operária etc.

Alzira, uma delegada de Rio Grande, fez diversas considerações sobre a organização da mulher operária e propôs especial atenção por parte da FORGS para organizá-las, incentivando sua participação através de periódicos, boletins, palestras e conferências (Rodrigues, 1969 , p. 62).

Entre as mulheres italianas militantes foi possível encontrar referências de Anna Libonati Avenna (1877-1961). Segundo Marçal, foi enfermeira, jornalista, poeta, teatróloga e militante anarquista. Nasceu em Nápoles e militou em Porto Alegre junto aos motoristas de praça, defendendo sua união. Em 1926 editou O Automobilista. Além de Anna, em 1909, Asérgia Della Pozza, descendente de italianos, costureira e artista de teatro amador, foi a primeira mulher que dirigiu uma entidade operária no Brasil, presidindo o Grêmio Operário Xavier da Costa (Marçal, s/d, p. 33).

O 4 Congresso ocorreu ao final da década de 1920, em 1928, este congresso teve "amplas proporções anarco-sindicalistas" (Rodrigues, 1969, p. 71). Nesta ocasiāo, os militantes de Porto Alegre propuseram que a reorganização da Confederação Brasileira (COB) tivesse "orientação genuinamente anarquista" (Rodrigues, 1969, p. 77). 


\section{Associações operárias e sindicatos}

Deve-se destacar que o Partido Socialista Rio-Grandense, fundado no final do século, não foi a organização que teve papel de maior destaque dentro do movimento operário da época, “(...) mas o sindicato que representa o órgão de aglutinação e ponta-de-lança de luta do operariado" (Carone, 1984, p. 77).

Em Porto Alegre, foram fundadas várias associações de classe. O Clube de Imprensa Operária foi criado em 1906, por iniciativa de Francisco Xavier da Costa. Neste ano, foi secretário do clube Carlos Macchi, então Presidente da União dos Trabalhadores em Madeira. Em 1907, assume uma nova diretoria tendo entre seus membros: Avelino Greco; Manoel Clemente Cavalcanti e Alberto Kruse. Esta agremiação teria sido porta-voz dos socialistas da FORGS (Marçal, 1985, p. 31).

O Círculo da Imprensa, fundado em 1911, tinha como objetivo específico a defesa dos interesses dos jornalistas. Entre os 6 membros de sua primeira diretoria provisória encontram-se Abrilino Lanza e Vicente Gianoni. Em nova reunião definiu-se a diretoria com sete membros, e os referidos anteriormente permaneceram em seu quadro.

O Sindicato dos Gráficos de Porto Alegre se originou a partir da Sociedade Tipográfica Rio-Grandense, fundada por dois militantes socialistas, sendo um deles Giuseppe Ferla, que também foi dirigente da Liga Operária Internacional (1895) e passou a veicular o ideal anarquista. Este sindicato foi fundado com o objetivo de regularizar o horário de trabalho, tanto nas oficinas em que eram pagos por obra, quanto naquelas em que eram pagos por jornada (A Luta, 10.10.1906).

A União dos Metalúrgicos, fundada em 1905 em Porto Alegre, confundia-se com os membros do Allgemeiner. Os membros desta União eram todos alemães até aproximadamente 1910. Na diretoria, composta por 11 membros, havia um descendente de italiano, Maximiliano Chagas Perachi.

A União dos Oficiais Barbeiros fundada por volta de 1913 tinha 60 membros. Surge depois como União Beneficente dos Oficiais Barbeiros de Porto Alegre, tendo como Presidente Geminiano Candiota Xavier. Finalmente, em 1931 foi fundado o Sindicato Patronal dos Salôes de Barbeiros, Cabeleireiros, Instituto de Beleza e Similares de Porto Alegre; entre seus membros fundadores estava Ernesto Conti, 
com quem Geminiano trabalhara de 1920 até 1963, no conhecido Salão Conti, sito na rua da Praia. Em 1932 surge o Sindicato dos Oficiais Barbeiros; os funcionários de barbearias passam então a se organizar.

O Sindicato dos Marceneiros e Anexos, fundado em 1907, tinha sua diretoria composta por alemães: Jung, Weith, Hartmann, Schimeifeiniger (?) e Hoffmann. Em 1907 também surge o Sindicato dos Operários Alfaiates, que, segundo Marçal, tinha orientação anarcosindicalista. Em 1911 foi fundada a União dos Oficiais Alfaiates. Esta organização se mobiliza para reivindicar aumento salarial e 9 horas de trabalho. Entre os 3 membros da diretoria está Angelo Bussolin.

O Sindicato dos Marmoristas, dirigido pelos anarquistas, teve a iniciativa e organizou o movimento grevista para conquistar 8 horas de trabalho. Serviu como vanguarda para que outras categorias também entrassem em greve. Em 1906, o tesoureiro do sindicato era Henrique Faccini, e a sede da entidade funcionava no Restaurante Faccini. Os Faccini são uma das famílias que fizeram parte da extinta Colônia Cecília (Rodrigues, 1984, p. 24).

A Sociedade de Resistência Padeiral foi fundada em 1905; em 1906 ficou conhecida como União dos Empregados em Padaria. A presença de italianos ao longo da existência da Sociedade é marcante: Antonio Digiorgio, Clemente Bidessi, Angelino Vitaletto, José Giratta e Humberto Laitano. Com a década anarquista, correspondente a 1910-1920, recebe o nome de Liga Padeiral, e conta com a participação de Italo Lena e Angelino Vitaletto.

A Associação dos Sapateiros foi fundada em 1901. A reunião de tendência socialista que deu origem a essa associação teve como oradores Pedro e Alberto Leão Mattiolli. A diretoria escolhida foi composta por Pedro Mattioli, Caetano Guaragna, Alberto Mattioli e Francisco Failace. Os responsáveis pela elaboração do estatuto foram: Jose Mazzaferro, Nicolau Scardini e Pedro Mattioli. Esta entidade desaparece e em seu lugar surge em 1911 a União dos Artífices Sapateiros, por iniciativa de Antonio Francisco Ferrugencio. A primeira diretoria foi composta por Tarquínio Strapazone, Francisco De Chiara, José Franco, Antonio Ferrugencio, Tomaz Apelliani e Frederico Leonardi.

Em 1909, foi fundada a Liga Beneficente dos Pintores; em sua diretoria estiveram João Antonio Cariboni e Francisco Seggiaro. Essa diretoria era surpreendentemente composta por alguns patrões. Em 
1918, entre os 14 membros três eram italianos: Dante Caselgrande, José Pegoraro e José Felipelli.

A União Operária Internacional fundada em 1905; de tendência anarquista, visava ocupar o espaço deixado com o desaparecimento da Liga Operária Internacional. Participaram desta União, José Macchi, Carlos Toffolo e Tarquínio Strapazone, Antonio Cariboni e Felicio Andreoli.

A União dos Chapeleiros foi fundada em 1906 com o nome de Sindicato de Resistência dos Chapeleiros. Participaram do Sindicato o anarquista José Regnoni, Francisco Degani e Marçal Feberti.

A União dos Pedreiros surgiu em 1906 atendendo ao manifesto dos marmoristas, que haviam iniciado e organizado o movimento grevista em 1906. A União iniciou suas atividades, chamando greve pelas 8 horas de trabalho. Entre os fundadores estavam Francisco Xavier da Costa, José Macchi, socialista, e Luiz Derivi. A União ficou ligada às idéias socialistas. Em 1909, a chapa de oposição vence as eleições, assumindo a diretoria Luiz Derivi, como presidente, além de Atilio-Fornari e João Perazzoni. Em 1909, com as comemorações do $3^{\circ}$ aniversário de fundação da União do Pedreiros, discursaram Luiz Derivi, Pedro Gianetti e outros da Associação dos Funileiros, dos trabalhadores em madeiras, dos empregados em padaria, Liga dos Pintores e Lyra Oriental (Correio do Povo, 12.9.1909). Em 1910 assume nova diretoria; entre os 10 membros estão Narciso Berleze, Atilio Fornari, João Toledano e Grigolo Nazareno.

Em 1907 o presidente da União dos Trabalhadores em Madeira foi Carlos Macchi. Esta união foi fundada em 28.10.1906, no bairro Navegantes, com o objetivo de tratar dos interesses da classe (A Luta, 15.11.1906).

A presença quantitativa de militantes italianos no movimento operário no RS é expressiva, chegando a cerca de $20 \%$. Somente na Associação dos Sapateiros verifica-se uma predominância quase absoluta de imigrantes italianos; nas demais associaçóes de classe ou de ofícios o representante italiano não predominou.

\section{Greves e outras manifestações}

As greves no Rio Grande do Sul começaram ao final do século XIX. A primeira greve ocorreu em 1890, em Pelotas, onde os tipógra- 
fos reivindicavam condições melhores no pagamento do salário (Petersen, 1980, p. 290). Além desta, outras greves irão acontecer até o início de nosso século. Em julho de 1890, o jornal A Pátria (jul. 1890 , n. 149 , p. 2) transcreve do Echo do Sul informaçôes sobre greve dos empregados da fábrica de tecidos Rheigantz \& Cia.

Em 1897 ocorre a primeira greve em Rio Grande (Echo Operário, 19.9.1897). Esta greve teve início em 15 de setembro; os tecelões da Fábrica Ítalo-Brasileira reivindicavam aumento salarial e obtiveram vitória parcial (Petersen, 1980, p. 291). A categoria mobilizada, em reunião na Uniāo Operária, participou de uma exposição e apreciaçāo do "inteligente operário Alpinolo Rossi em idioma italiano" (Echo Operário, 26.9.1897).

Os movimentos paredistas, em geral, inicialmente visavam a reivindicação de melhorias salariais, diminuição das horas de trabalho, atos solidários etc.

Em 1906 ocorre em Porto Alegre a primeira greve geral. Esse movimento teve a iniciativa do Sindicato dos Marmoristas, cuja maioria dos filiados trabalhava na marmoraria Friederichs; os operários reivindicaram, em carta (Núcleo UFRGS, 194 E), 8 horas de trabalho; assinou a referida carta Henrique Faccini. Faccini, em matéria no jornal Gazeta do Comércio escreve:

"Os marmoristas asseverando várias pessoas que os ex-grevistas
da oficina do Sr. J. Friederichs voltaram ao trabalho, nāo por
efeito de acordo e, que saíram vitoriosos, e sim submetendo-se,
declaro em nome do Sindicato dos Marmoristas que as principais
cláusulas ajustadas com o referido Sr. Friederichs pelo nosso de-
legado companheiro Xavier da Costa, e dos quais resultou o fim
da greve foram os seguintes: concedido 8 horas, pagamento por
hora, ex-grevistas não despedidos. Porto Alegre, 28.09.1906.
Pelo Sindicato. Henrique Faccini" (Gazeta do Comércio,
1.10.1906).

Os marmoristas, como se vê, saíram vitoriosos da greve e demonstraram força e organização.

Outras categorias participaram do movimento grevista. Segundo Petersen, participaram os operários de fundições, de pedreiras, de fábricas de doces, curtumes, funilarias, fábricas de vidro, chapéus, sabões, móveis, gravatas, meias, Cia. Força e Luz, fiação e tecelagem, estaleiros e estiva (Petersen, 1980, p. 291). 
Através da imprensa, especialmente a operária, foi possível constatar a grande mobilização em torno da obtenção da jornada de 8 horas e do aumento salarial.

Em reunião convocada, os pedreiros são conclamados a participar do movimento grevista em prol das 8 horas. Nesta ocasião foi fundada a União dos Pedreiros "para promover a solidariedade entre a classe e bem assim metodizar os meios de luta pelas reivindicações de seus direitos" (A Luta, 13.9.1906).

Oliveira Diamico, em artigo, conclama os gráficos a se organizar para a obtenção da jornada de 8 horas. Reclama do imobilismo do Grêmio Tipográfico, que não preenche os fins para que foi criado. Reclama por fim da necessidade de um tempo livre "indispensável ao cultivo e desenvolvimento do princípio inteligente que o homem encerra em si, sem o que não pode ser útil nem a si nem à grande órfã - a Humanidade" (A Luta, 29.9.1906). A necessidade de um tempo livre foi também uma das razões de luta pelas 8 horas. No mesmo número do periódico, Valentim De Cesaro publica artigo onde critica o socialismo parlamentarista, assinalando fatores que se antepõem ao desenvolvimento da coletividade.

No dia 4.10.1906, foram paralisadas as oficinas de Astiolli, Tomatis e Carlos Ottoni (Gazeta do Comércio, 4.10.1906). Os alfaiates não aderiram ao movimento, em reunião convocada, que tinha na pauta greve e sociedade de resistência; os alfaiates não compareceram e só o fariam se fosse em reunião para tratar de uma Associação Beneficente (A Luta, 10.10.1906).

O jornal A Luta do mesmo dia comenta também sobre uma reunião dos presidentes das associações operárias da capital, à qual compareceram diversos representantes. Na primeira sessão dos pedreiros um dos oradores atacou os anarquistas. José Macchi, que havia convocado a sessão, afirmou que ali não havia lugar para anarquistas, tendo muitos representantes se retirado, entre eles Henrique Faccini, dos marmoristas, e José Rognone, da União dos Chapeleiros.

O ano de 1906 é um marco no movimento operário do Rio Grande do Sul e particularmente em Porto Alegre; é o ano da investida anarquista versus socialistas pela hegemonia da vanguarda dos movimentos.

Apelos foram feitos na imprensa (A Luta, 10.10.1906), para que os padeiros entrassem em greve, aproveitando o momento para a obtenção do descanso dominical. Por outro lado, nesta ocasião, também 
entraram em greve os ferreiros, operários da Ferraria e Serralharia de João Raminelli, além de trabalhadores de outra ferraria.

As autoridades, em defesa do capital, vão autuar alguns grevistas, recolhendo-os ao presídio. Foram presos um italiano e dois alemães (Correio do Povo, 13.10.1906).

Espártaco Pisacani publica um artigo sobre as razões da greve, no qual aborda a procura de um viver nobre e julga que a experiência adquirida durante as greves é uma verdadeira lição para a vida (A Luta, 28.10.1906).

A greve geral de 1906 foi gradativa e, em cerca de oito dias, a paralisação era praticamente geral. Neste momento é fundada a Federação Operária do Rio Grande do Sul (FORGS). Inicialmente a corrente anarquista não tomou parte na Federação, tendo assumido o grupo social-democrata. Somente a partir de 1910-1911 os anarquistas alcançam a hegemonia na FORGS. A Federação tinha como fim agrupar as diversas associações existentes em Porto Alegre: União dos Pedreiros, Sindicato dos Marmoristas, União dos Trabalhadores em Madeira, Sindicato dos Marceneiros, Grêmio de Artes Gráficas, União de Resistência dos Empregados em Padaria, União Operária Internacional e Algemeiner Arbeiterverein (Marçal, 1985, p. 24).

Sob o domínio anarquista, a FORGS agrupou um número razoável de operários amadores de música na Lyra Operária, com o objetivo de constituir uma banda musical para festas operárias.

A diretoria eleita em 1911 era composta pelos anarquistas Luiz Derivi, Polidoro Santos e Joaquim Hoffmeister. Os delegados italianos, por categoria, foram: Tarquínio Strapazoni, Lyra Operária; Frederico Leonardi, Uniāo dos Artífices Sapateiros; e Antonio Francisco Ferrugêncio, Centro dos Trabalhadores/Passo Fundo.

Na comissão editora da Voz do Trabalhador estavam os italianos Antônio Cariboni, Luiz Derivi e Carlos Toffolo, além de Polidoro Santos e Jeronymo Baptista.

Os Estatutos da FORGS tinham como objetivo alcançar os meios de ação para a greve, a ação direta e os meios de propaganda, como jornais, tribunas, escolas, livros e praças públicas.

Do ponto de vista do Relator Chefe de Polícia, Pedro Mibielli, nos dias $1^{\circ}$ e 2.10.1906, 4.000 operários se declararam em greve, com o objetivo da obtenção das 8 horas de trabalho, "velho princípio socialista” (Núcleo UFRGS, 040 E). Mibielli lembra também a lei orgânica $\mathrm{n}^{2} 11$ de 4.1.1896, que prevê serviço da polícia preventiva a 
cargo do Município, enquanto ao Estado foi reservado privativamente o serviço da polícia repressiva.

O movimento organizado das diversas categorias permaneceu mobilizado e ao longo da década de 1910 novas greves serão deflagradas.

Os italianos não fazem parte de forma hegemônica do movimento operário em Porto Alegre, como fizeram em São Paulo. São poucos os imigrantes envolvidos nestes movimentos, os que participam fazem-no em diversas organizações ao mesmo tempo ou ao longo do período, não havendo renovaçã́o de nomes.

Mas então, onde estão os imigrantes italianos e seus descendentes? Talvez seja possível encontrá-los ao seguir novos passos significativos do movimento operário em Porto Alegre.

Somente em 1911 fundou-se a União dos Oficiais Alfaiates, tendo como tesoureiro Angelo Bussolin. Logo a seguir foi deflagrado um movimento paredista, em que os alfaiates reivindicam aumento salarial e jornada de 9 horas. Neste movimento (Petersen, 1980, p. 292) somente alguns patrôes fazem concessões.

Muitas outras greves serão deflagradas ao longo da década de 1910. Duas greves de calceteiros ocorreram em 1916. Sobre uma delas o jornal A Federaçáo escreve que o sindicato quer a expulsão de capatazes devido aos maus tratos. Como não foram atendidos, deram início à greve com grande adesão, principalmente de estrangeiros. Após a realização de comícios, desenrolaram-se "cenas de selvageria". Um dos diretores do movimento grevista, o canteiro espanhol Saturnino Sandoval, agrediu um dos 20 operários que trabalhavam na turma da Rua da Conceição, o servente Antonio Fabretti, de 50 anos, e o agressor fugiu. Os trabalhos continuaram e um grupo de operários grevistas armados agrediu outra turma que trabalhava, sendo atingido com arma de fogo João Manoel Bervetti. Segundo o jornal, as investigações policiais apuraram responsabilidade criminal dos seguintes elementos: Angelo Cavanellas, Felipe Pietro, Constantino Gio, Ramão Ciarco.

Os agredidos são os chamados "fura-greves" e são italianos; já os responsáveis, segundo a polícia, a julgar pelos sobrenomes, são provavelmente dois espanhóis e dois italianos.

A greve geral de 1917 foi uma greve em que os operários, com experiência em movimentos anteriores mobilizaram-se e foram mobilizados nas mais diversas categorias. 
"A reivindicação principal desta greve geral foi o aumento salarial e Borges de Medeiros, demonstrando sua maneira pessoal de tratar os problemas do trabalho, concedeu aumento salarial aos proletários a serviço do Estado (Decreto 2287 de 1917) e deu instruçōes ao intendente da capital e à Brigada Militar para atuarem junto aos empresários, muitos dos quais acederam às reivindicaçōes operárias. Borges também proibiu temporariamente a saída de gêneros alimentícios para fora do Rio Grande com a finalidade de diminuir a escassez local" (Petersen, 1980, p. 281).

O Correio do Povo (31.7.1917) registra o aparecimento, em bairros operários, de um boletim de convocação do Sindicato dos Pedreiros, Carpinteiros e Classes Anexas, convidando para reunião na sede da FORGS; a referida reunião foi aberta por Luiz Derivi, membro do Sindicato. Nesta ocasião foi criada a Liga de Defesa Popular (LDP), sendo nomeados os líderes: Luiz Derivi, Cecílio Villar, Salvador Rios, além dos operários Vigo Collin, Carlos Toffolo e Pedro Ferrari.

Em busca de solidariedade e paralisação geral, um grupo de populares, apedrejou o estabelecimento de Crivellaro e Difini (Correio do Povo, 1.8.1917) fábrica de banha e depósito de vinho. Os trabalhadores deste estabelecimento, cerca de 56 operários, se recusaram a paralisar. De outro lado, uma Comissão da Liga de Defesa Popular percorreu diversas sapatarias, reivindicando ao lado dos empregados o horário de 8 horas e o aumento de $25 \%$ nos salários. Alguns estabelecimentos entram em entendimento e se comprometem a cumprir o acordo; são as casas de Nicola Mastroberti, Luiz Guaragna, Luiz Fredi, Pascoal Domenico, Silvio Felipozzi (3 empregados) e Antonio Saccodato (4 empregados).

A adesão é parcial (Correio do Povo, 2.8.1917). Muitos operários abandonaram o serviço, entre eles os das fábricas Damiani \& Irmãos, pequena oficina de móveis e decorações que no ano anterior contava apenas com seis empregados, e Sanguinetti \& C., também fábrica de móveis e decorações com cerca de 30 empregados. Segue o mesmo jornal informando que a Padaria Italiana, sita na Praça da Harmonia, não aderiu ao movimento e teve garantido o trabalho pela polícia. Já os trabalhadores das casas Domingos Felippeto e Caetano Fulginiti aderiram à paralisação. Em solidariedade ao movimento, os operários da Destilaria Scalzilli abandonaram o serviço; cerca de 
20 operários trabalhavam em 1916 para Nicolau Scalzilli e 15 para Januário Scalzilli.

Nesta greve, enquanto alguns proprietários "concedem o reivindicado por seus empregados, outros não concordam com o movimento. Os proprietários de alfaiatarias, por exemplo, não concordaram com o pedido apresentado de aumento salarial; dirigiram à Liga de Defesa Popular um ofício onde assinam os proprietários que não abrirão seus estabelecimentos: Roque Fiori, Alberico Bernardi, Paulino Bernardi, Alves \& Cerone e Masi \& Sasso (Correio do Povo, 4.8.1917).

Segundo o Correio do Povo, em 6.8.1917, uma comissão de caixeiros de lojas dos $3^{\circ}$ e $4^{2}$ distritos, acompanhada de um representante da LDP, percorreram diversas lojas de fazendas, solicitando que as mesmas fechassem seus estabelecimentos às $19 \mathrm{~h} 30 \mathrm{~min}$ no inverno e às 20 horas no verão; concordaram com a solicitação o Sr. José Failho Vianna e Alfredo Ungaretti. Porém, a maioria dos proprietários solicitados a diminuírem as horas de serviço para inverno e verão recusaram-se a fazê-lo: Domingos Rizzo, artigo folhas de flandres - 2 operários; Natale Grimaldi, massas alimentícias - 14 operários; José Floriani, marmoraria - 12 operários; José Piccoral, fumos preparados 10 operários; José Sanguinetti, móveis e decoração - 30 operários; Carlos Collin, Domingos Felippeto, Caetano Fulginiti, Alfredo Signoretto, Serraria Garibaldi e Fortunato Travi.

Os fabricantes de móveis que haviam fechado seus estabelecimentos, pela paralisação de seus empregados ou motivos outros, decidiram em reunião reabrir suas fábricas: Arbos Pezzani (80 empregados em 1916), Daniel Collin, Domingos Felippeto, José Darianio, Caetano Fulginiti, José Sanguinetti e Bruno Mareco (Correio do Povo, 7.8.1917).

Algumas casas ou empresas, durante o movimento grevista, fizeram "concessões" aos seus empregados, aumentando salários ou diminuindo as horas de trabalho. Entre esses estabelecimentos, significativo era o número de proprietários italianos: no ramo de ferrarias, José Arconza Berna, Irmãos Tellini e Paulo Paganini e Roberto Ramoli; nas Sapatarias Perrone, Salvador Cavale (93 empregados), Luiz Fredi, Pascoal Demini, Silvio Felippozi, Francisco Cruccio, Januario Viguoti, Paulino Derole e Salvador Micelli; nas alfaiatarias, João Meneghetti; a Tipografia Stella D’Italia; nas funilarias, Luiz Mainoni, Pedro Crivellaro e Felippe Caselli; nas fábricas de licores, Scalzilli, 
Santo Meneghetti e Francisco Maineri; nas construtoras, Luiz Pallini, Luiz Ortiali e Domenico Vigna; a Fábrica de Chapéus de Germano Bartolo, a Padaria de Pedro Zoratto e a Barbearia de Spitalheiri (Correio do Povo, 7.8.1917).

Percebe-se, diante dos dados colhidos, que no grupo de imigrantes italianos predominam, quantitativamente, os pequenos e médios proprietários de alguns estabelecimentos que, em regra, contam com reduzido número de empregados.

A greve de 1917, além de paralisar várias categorias, estimulou o surgimento de novas organizações. Segundo periódico da capital (Correio do Povo, 7.8.1917), foram fundados os sindicatos dos sapateiros, dos trapicheiros e estivadores, dos operários da Cia. Força e Luz, dos chapeleiros, dos alfaiates, dos tecelōes e a União dos Condutores de Veículos.

Outro periódico da capital (O Imparcial, 6.8.1917) registra, como causas da greve, a carestia de vida, a escassez de gêneros e grande movimento de exportação dos gêneros provocado pela $1^{\text {a }}$ Guerra Mundial, quando foram exportados artigos básicos alimentícios, havendo por isso uma elevação dos preços para os consumidores locais.

Os trabalhadores que obtiveram vitória foram gradativamente voltando ao trabalho, enquanto em outros estabelecimentos a greve continuou parcialmente, até que todos os operários assegurassem suas reivindicações. Segundo O Imparcial, a greve teve o apoio popular, pois a partir desta movimentação foi possível a regulamentação dos preços dos gêneros de consumo e a limitação das exportações.

A atitude paternalista, assumida por Borges de Medeiros objetivava o lucro político tendo em vista a sucessão presidencial que deveria ocorrer no ano seguinte. "O receio de uma sucessão presidencial favorável a Rui Barbosa, o veterano contestador da Constituinte de 1891, fez com que o governo Borges de Medeiros buscasse, na resolução dos problemas do Estado, coesão interna e prestígio nas altas esferas políticas" (Kliemann, 1980, p. 237).

A convergência de interesses do governo, associada às necessidades da população em geral e do proletariado, fez com que sob "proteção de Borges de Medeiros", a sociedade naquele momento saísse vitoriosa, o que não impediu a repressão nos movimentos posteriores. 
Santo Meneghetti e Francisco Maineri; nas construtoras, Luiz Pallini, Luiz Ortiali e Domenico Vigna; a Fábrica de Chapéus de Germano Bartolo, a Padaria de Pedro Zoratto e a Barbearia de Spitalheiri (Correio do Povo, 7.8.1917).

Percebe-se, diante dos dados colhidos, que no grupo de imigrantes italianos predominam, quantitativamente, os pequenos e médios proprietários de alguns estabelecimentos que, em regra, contam com reduzido número de empregados.

A greve de 1917, além de paralisar várias categorias, estimulou o surgimento de novas organizações. Segundo periódico da capital (Correio do Povo, 7.8.1917), foram fundados os sindicatos dos sapateiros, dos trapicheiros e estivadores, dos operários da Cia. Força e Luz, dos chapeleiros, dos alfaiates, dos tecelões e a Uniāo dos Condutores de Veículos.

Outro periódico da capital (O Imparcial, 6.8.1917) registra, como causas da greve, a carestia de vida, a escassez de gêneros e grande movimento de exportação dos gêneros provocado pela $1^{\text {a }}$ Guerra Mundial, quando foram exportados artigos básicos alimentícios, havendo por isso uma elevação dos preços para os consumidores locais.

Os trabalhadores que obtiveram vitória foram gradativamente voltando ao trabalho, enquanto em outros estabelecimentos a greve continuou parcialmente, até que todos os operários assegurassem suas reivindicações. Segundo O Imparcial, a greve teve o apoio popular, pois a partir desta movimentação foi possível a regulamentação dos preços dos gêneros de consumo e a limitação das exportações.

A atitude paternalista, assumida por Borges de Medeiros objetivava o lucro político tendo em vista a sucessão presidencial que deveria ocorrer no ano seguinte. "O receio de uma sucessão presidencial favorável a Rui Barbosa, o veterano contestador da Constituinte de 1891, fez com que o governo Borges de Medeiros buscasse, na resolução dos problemas do Estado, coesão interna e prestígio nas altas esferas políticas" (Kliemann, 1980, p. 237).

A convergência de interesses do governo, associada às necessidades da população em geral e do proletariado, fez com que sob "proteção de Borges de Medeiros", a sociedade naquele momento saísse vitoriosa, o que não impediu a repressão nos movimentos posteriores. 
Em 21.7.1918, foi decretada outra greve geral, reivindicando-se: "1 - Abaixamento de $40 \%$ nos preços atuais dos gêneros de primeira necessidade; 2 - Regulamentação 8 h diárias de trabalho; 3 - Liberdade aos operários canteiros que se acham recolhidos à casa de correção; 4 - Criação de uma lei de proteção aos operários, vítimas de acidentes de trabalhos; 5 - Instituição das passagens de bondes de 100 réis para os operários" (Notícia, 20.7.1918).

Após reunião na FORGS, algumas categorias foram aderindo à paralisação: os motorneiros paralisaram o tráfego de bondes às 18h30min; os operários da Usina Força e Luz abandonaram o trabalho, sendo a Usina Municipal guardada pela Brigada, e no dia seguinte os bondes foram guardados por praças. Foram calculados nesta paralisação cerca de 1.500 operários grevistas (Notícia, 22.7.1918).

A pretendida greve geral de 1918 não teve a mesma sorte que a anterior e culminou com o fechamento da FORGS. Em entrevista realizada com um grevista, este demonstrava desânimo em relação à classe, que considerou desunida. Em relação ao fechamento da Federação, o grevista afirmou: "Não há chefes, é uma anarquia", e atribuiu esse fato "talvez a espanhóis agitadores, vindos de São Paulo" (Notícia, 23.7.1918).

Em agosto de 1919, foi deflagrada outra greve dos operários das fábricas de Fiação e Tecelagem que ainda reivindicavam aumento salarial e diminuição da jornada de trabalho. Outras categorias aderiram ao movimento (Petersen, 1980, p. 316). Entre os vários estabelecimentos paralisados estavam: Serraria Garibaldi, Confeitaria Rocco, Fábrica de Banha Maristani, Maisonave \& Cia. Vários incidentes ocorreram em início de setembro durante a realização de um comício. A Brigada foi convocada para dissolver a manifestação; com isso houve muitos feridos e uma vítima fatal, o operário João Puppi. Após essa série de acontecimentos, as associaçôes operárias foram fechadas.

"Apesar das vitórias e acordos feitos com os patrōes, outra constatação que se faz, do estudo destas greves (confirmando, aliás, o privatismo que imperava na regulamentação das relaçōes de produçâa), que a soluçáo dos conflitos se dava no âmbito das relaçôes privadas, sem nenhuma garantia legal para o operário; desta maneira, muitas vezes os ajustes podiam ser rescindidos a qualquer momento, por uma simples resolução dos patrổes. Isto, em geral ocorreu com respeito à redução da jornada: concordavam 
em reduzir o tempo do trabalho, mas o empregador, a seu critério, reduzia o salário (...)” (Petersen, 1980, p. 323).

$\mathrm{Na}$ descrição dos movimentos grevistas ocorridos em Porto Alegre, a incidência de imigrantes italianos é maior entre os proprietários, resolvendo os conflitos surgidos em seus estabelecimentos, com toda a liberdade e aval do Estado. A presença de imigrantes italianos envolvidos em movimentos paredistas, enquanto trabalhadores, foi pequena. Os nomes arrolados entre as diretorias de sindicatos e associaçốes, em sua maioria, se repetem, ou seja, um pequeno número de imigrantes italianos se engajou nos movimentos operários do período; há que considerar também aqueles que se dirigiram para a Capital com o objetivo de promover a organização e unificação do movimento, militando de passagem por Porto Alegre e não residentes da cidade.

\section{Comemorações e solidariedade}

Uma das datas mais importantes para os trabalhadores e para o movimento operário em geral é o $1^{\text { }}$ de Maio. Esta data lembra as vítimas de Chicago (Frigerio, 1986, p. 271), massacradas em maio de 1886 , e também serve como um ato de protesto contra as condições dos trabalhadores em geral.

As primeiras notícias de comemoração do $1^{\circ}$ de Maio no Rio Grande do Sul vieram de Pelotas, através da Liga Operária, em 1893 (Petersen, 1981, p. 23-4). Marçal aponta como a primeira comemoração do $1^{\circ}$ de Maio em Porto Alegre o ano de 1892 , por obra dos anarquistas coincidindo com o ano de edição do L'Avvenire por Leoni (Revista Sul, s/d, p. 32). Em 1894, em Rio Grande, foi instalada a União Operária no dia $1^{\circ}$ de maio, quando foi comemorada a data. Esta sociedade orientada por princípios socialistas, foi organizada e dirigida por operários.

As comemorações do $1^{\circ}$ de Maio inicialmente eram eventos festivos, para após passarem a um ato de protesto contra o capitalismo brasileiro. Pela primeira vez, o dia $1^{\circ}$ de Maio foi comemorado em Porto Alegre em 1892, sendo registradas pequenas notícias em alguns periódicos da capital (Petersen, 1981, p. 33).

As comemoraçốes do 1.5.1904, em Porto Alegre, tiveram características diferentes das comemorações realizadas em São Paulo, de 
tendência anarco-sindicalista. “(...). O aspecto lúdico do piquenique no Prado (Porto Alegre) ressalta o desenrolar de uma celebração do trabalho ainda nos limites da independência de classe, porque não patrocinada pelo governo ou empresários ao contrário da já descaracterizada e populista 'festa do trabalho' carioca, padrão este que se repete em Teresina, em 1906" (Hardman, 1984, p. 45).

Em 1897, Giuseppe Ferla escreve para os italianos. Ferla veio para o Brasil com o grupo do Dr. Giovanni Rossi para a Colônia Cecília, experiência anarquista no Paraná. Tendo fracassado o objetivo da Colônia, elementos que dela fizeram parte se deslocaram para centros urbanos. Ferla radicou-se aqui em Porto Alegre, constituindo família e militando no meio operário; foi um dos fundadores da União Tipográfica. Escreve aos operários italianos sobre o $1^{\circ}$ de Maio:

"Este dia festivo não, por esta ou outra nação, é o dia de mostrar a solidariedade entre todos os explorados do Universo; é o dia de protesto Universal da classe que trabalha, produz, sofre e nada usufrui contra a outra que, ociosa, preguiçosa, exploradora e passa a vida inteira em completo prazer, com o produto do suor do operário, é o dia enfim de mostrar à curiosidade burguesa os nossos farrapos, as nossas mangas, as nossas profundas rugas, o nosso dorso recurvo, e tudo em virtude do martelo, do prumo e dos outros instrumentos de trabalho que o sistema capitalista... Não deixemos passar inobservada esta data, não façamos 'orecchio di mercante' ao apelo que os nossos irmãos te fazem, não sejamos surdos ao grito de protesto que de um só ímpeto e com um só coração e com uma só boca.(...) Operários Italianos ... Participemos também nós ...deste ato de solidariedade; não somente hoje, mas sempre e sempre ... Giuseppe Ferla" (Gazetinha, 1.5.1897).

Outro periódico, A Voz do Operário, registra que em sessão realizada em 11.8.1893, um congresso em Zürich deixou claro que a manifestação de $1^{\circ}$ de Maio era o "verdadeiro caráter de reivindicação do dia normal de 8 h de trabalho e de afirmação da luta de classe" (1.4.1899).

O jornal Avante transcreve o programa para a comemoração do 1.5.1902: "8:00 h - reunião na sede social das Associações operárias. 14:00 h -reunião das famílias dos companheiros, na sede das Associações, onde realizar-se-ão diversōes múltiplas: 20 h - conferência pública no Polytheama Porto Alegrense" (29.4.1902). A conferência 
pública realizada dentro das comemorações daquele $1^{\circ}$ de Maio foram vertidas também em alemão.

O jornal operário A Voz dos Oprimidos dedica toda a edição a artigos sobre o $1^{\circ}$ de Maio; um deles, escrito em italiano, tratando de aspectos da luta de classe, encerra o artigo assim: "Viva ... L'Emanzipazione dell'umanità" (1.5.1903). O Jornal Social (Alegrete, 23.4.1899), do interior, anuncia também festejos para o 1.5.1899.

Outro aspecto do Movimento Operário era a solidariedade a outros companheiros por ocasião dos movimentos grevistas, como foi visto, ou nas dificuldades enfrentadas por demissão, morte etc.

O jornal A Luta (15.11.1906) publica um apelo aos operários para ajudar aos que, em razão das greves, ficaram desempregados. Entre as muitas colaborações, uma foi de Sabino Chincoli. Outro apelo feito pelo jornal foi a solicitação de auxílio à viúva e filhos de Rodolfo Pflugrath. Contribuíram Giuseppe Ferla, Pedro Mattioli e Francisco Faillace (17.1.1907).

Um exemplo de solidariedade foi mostrado por ocasião de greve parcial realizada pelos operários do Lloyd Brasileiro. Os diretores da referida companhia, a fim de preencherem os espaços dos que continuavam em greve, procuraram mandar vir operários de outros países para efetuar a substituição. Chegou então à capital um grupo de operários portugueses que, ao saberem dos reais motivos, recusaram-se a trabalhar. Outro ato solidário foi por ocasião da greve dos operários da Marmoraria Friederich onde o proprietário foi para o Prata em busca de operários. A reação foi a mesma: quando souberam dos motivos, manifestaram-se solidários com as reivindicações de seus colegas de Porto Alegre (A Luta, 15.12.1906).

\section{Imprensa operária italiana}

A imprensa foi um dos principais meios de comunicação, senão o principal, na virada do século. Publicações como jornais, panfletos, volantes, revistas etc. ao passar de mão em mão iam cumprindo seus objetivos, ou seja, ampliando a luta operária. No Rio de Janeiro, “(...) particularmente entre os imigrantes italianos, havia o hábito de comprar um único exemplar de jornal para grupos inteiros de pessoa que 
se reuniam em volta de quem lia em voz alta o noticiário" (Cenni, 1975 , p. 226).

A iniciativa de publicações sobre o movimento operário pressupõe mínimas condições financeiras e a existência de leitores fora do âmbito dos próprios promotores da iniciativa. O surgimento da imprensa operária no Brasil foi expressão de um grupo consciente, que pretendeu propagar suas idéias e ideais. Através da publicação de jornais operários, pretendia-se organizar, mobilizar e estimular o movimento. Devido à falta de recursos financeiros, muitas dessas publicações tiveram pouca duração, o que não diminuiu sua importância. "As publicações não alcançam longa duração, como a têm os importantes órgảos de imprensa das classes dominantes, mas como demonstração da autenticidade e da vitalidade do Movimento Operário Brasileiro, aparecem e reaparecem aqui e ali, a breves intervalos, formando um fluxo praticamente ininterrupto (...)" (Garcia, 1964, p. 265).

Em Porto Alegre, a imprensa operária atravessou idênticas dificuldades e objetivava os mesmos fins. Contou com variados títulos publicados, mas, no que diz respeito à imprensa operária italiana, o número foi bastante reduzido, se for comparado com a imprensa italiana produzida em São Paulo.

Sabe-se da existência de apenas quatro jornais operários italianos, em Porto Alegre, comprometidos com os trabalhadores, especialmente com trabalhadores italianos.

Em 1892, é fundado o L'Avvenire, dirigido por Colombo Leoni, que mantinha relações com a Colônia Cecília. Este jornal é considerado por muitos como de tendência anarquista, talvez pela associação com a figura de Leoni. Neste primeiro número, Leoni discursou sobre a necessidade de fundar um partido. Ora, a existência de um Partido vai contra os princípios anarquistas, que vêem no partido um instrumento burguês de dominação.

Apesar de solicitar solidariedade, tem-se a impressão de que não se trata de solidariedade em conseqüência de açōes políticas. Matéria assinada por Gio. Paolo Locatelli conclama os italianos a votarem na próxima eleição do Estado e ensina como votar. Escreve Locatelli sobre o dever de o estrangeiro participar politicamente, no país que o hospeda (L'Avvenire, 7.3.1892).

Em 1896 é fundado o La Scintilla, dirigido pelo professor R. Ferraro, redigido por G. Vitola e de propriedade de Angelo Laporta di Filippo. Em seu editorial afirmam que: "O jornal milita em favor da 
classe proletária, ocupando-se em modo particular de suas necessidades, de seus direitos e de seu não distante porvir". (...) "La Scintilla, como órgão democrático, quando o espaço permitir, escrever sobre a vida dos homens mais eminentes que militaram para o bem do povo, sacrificando-se para a grande idéia do resgate Universal" (22.11.1896).

Este jornal, de tendência claramente socialista, apresenta também no primeiro número informações sobre a festa da Proclamação da República. Caracteriza-se o jornal pela utilização de diversas propagandas comerciais. Enfim, é um jornal que informa sobre os mais diversos assuntos, como acidentes mortais, a exemplo do que ocorreu com a filha menor de Giovani Barone.

O L'Operaio Italiano é referido por Petersen (1989, p. 67). Seu primeiro número é de 1899 . Não foi encontrado nenhum exemplar para verificar data de fundação, direção etc.

Finalmente o La Verità, fundado em 1902, teve como diretor Arduino Lippi, anarquista. No editorial do primeiro número afirma-se como um jornal que combate para o povo. Resumindo, escreve que se propõe a "(...) dar aos italianos um jornal essencialmente italiano; combater o egoísmo, a violência, a prostituição das idéias e o tráfico de publicações, com conceitos justos e morais, lutando contra todos os malvados etc."(1.7.1902)

Outro jornal operário, em língua portuguesa e tipicamente anarquista é A Luta. Este periódico para existir utilizou-se de subscrições, em listas, encontrando diversos responsáveis e contribuintes italianos.

No exemplar de 29.9.1902, aparece listagem de contribuintes: Anselmo Pettenuzze, Massinio Pettenuzze, J. F. Nasi, Ferla, Rognome Amilcare Meucchi, Otto Meucchi, Franzotti, Carlos Toffolo de Cezar Pianetti, Francisco Guaragna, Pedro Miquienzi, Felice Siga, Francisco Failace, Gaetano Rosito, Mazzaferro Carlos di Lorenzi, Valentin, Luigi Tamanini, Santo Cieroni, Giovani Vidas, Orcini Scardall, Leopoldo Pettenuzze, Achille Bestaluci. No número 10.10.1906, os contribuintes foram os seguintes: José Forti, Arquimedes Fortini, C. Camaroti, Francisco Raya, Carlos Demange, Hegídio Sonsini e Francesco Guariento. Em 28 de outubro do mesmo ano: Genovese, Andrizhetio, Nasi, contribuição proveniente da venda de seis cadeiras do extinto Circolo di Studi Sociali João Meregalli, Luiz Scoruso, C. De Rose, Afonso Cosso, Bonna, Rocco Rosito, Christini, Dante Manghi, Ernes- 
to Baseti, Antonio Gagi, Higino Bertangna, José Ponati, Luiz Faccini, Mario Delapicola, Alberto Pianta e Carlos Alberti.

Como responsáveis pelas listas de contribuição, são arrolados os seguintes nomes: Cezar Pianetti, Mazzaferro, Valentin De Cesaro, Domingos Felippetto, Franzotti, Roberto Bonna, José Forti e José Rognome.

As listas visavam angariar recursos financeiros para novas edições. Possível explicação para a contribuição de imigrantes italianos pode ser a solidariedade étnica, ou apenas uma contribuição que não significava necessariamente um vínculo com a ideologia do jornal; a hipótese de serem estas listas de contribuição provenientes de militantes, comprometidos ideologicamente, não é de todo descartada, mas somente no que se refere àqueles nomes arrolados em organizações operárias, anteriormente citados. Os novos nomes, se fossem militantes ou intelectuais, provavelmente teriam sido encontrados ao longo dos movimentos e associações operárias estudados, o que não ocorreu.

Uma lista de 10.10.1906, sob responsabilidade de Domingos Fellipetto, chama a atenção, pois posteriormente o mesmo é proprietário de fábrica de móveis (1917); isto pode ter ocorrido em 1906, quando o mesmo não era ainda proprietário, ou seja, estava ao lado dos assalariados ou explorados. Em 1917 sua postura vai ao encontro de seus novos interesses.

As assinaturas e as contribuições realizadas por imigrantes italianos a jornais não representam necessariamente um comprometimento ou identificação com a ideologia e/ou causa por eles defendida.

Entre os elementos do grupo italiano urbano, no caso de Porto Alegre, há grande incidência de meridionais, especialmente calabreses. Apesar da economia do sul da Itália permanecer predominantemente baseada em atividades primárias, os imigrantes oriundos desta região eram politizados ou conscientes das injustiças e dos direitos dos trabalhadores. Isto se comprova através de carta enviada em 1920 por Pasquale Donadio (Capelli, 1982, p. 120) ao jornal Vita Nuova, órgão do Partido Socialista publicado em Morano Calabro a partir de 1913. Donadio, imigrante em Porto Alegre e proprietário de um salão de barbeiro, apresenta congratulações aos grevistas tosadores de lã na sua terra natal.

O jornal Vita Nuova, importante publicação entre a colônia italiana urbana de Porto Alegre, tinha aqui o seu $3^{\circ}$ maior número de 
assinantes, com número inferior somente ao núcleo de Nova York e de Cienaga, na Colômbia. Este fato, por si, não significava que os assinantes fossem militantes socialistas em Porto Alegre. Escreve Capelli: “(...) a viva e intensa relação dos emigrantes com o jornal e com o Circolo Socialista não é sustentada somente por motivação política e classista. O jornal é também, de maneira evidente, um intermediários para manter mais sólidas as relaçóes com a comunidade de origem" (1982, p. 120).

Capelli exemplifica essa situação ao relatar sobre Pasquale Rosito, um representante do jornal Vita Nuova, na Guatemala. Rosito é proprietário de uma fábrica de calçados e, em 1922, em razão do repatriamento, decide vender sua propriedade e bens, avaliados aproximadamente em 88.000 dólares; o referido autor afirma que este é um “(...) exemplo indicativo de como o laço ideológico e prático com Vita Nuova nem sempre comporta um coerente compromisso de classe do emigrado, que neste caso vive evidentemente a relação com a comunidade moranesa só como laço para manter os contatos com a comunidade de origem" (1982, p. 126).

Os imigrantes italianos de origem meridional se estabeleceram em centros urbanos, atuando nas mais diversas atividades comerciais, industriais ou artesanais.

No Rio Grande do Sul, os moraneses se concentraram na capital, onde "(...) tornam-se ambulantes, vendedores de frutas, charcuteiros, açougueiros, sapateiros, barbeiros e por vezes profissionais liberais". "Mas muitos entre os moraneses conseguem realizar também notável fortuna econômica" (Capelli, 1982, p. 8797).

Da mesma forma como ocorre com o jornal Vita Nuova, os jornais operários, em idioma italiano, anteriormente analisados, procuram agrupar e estimular os italianos em busca de uma identidade, mesmo que essa fosse encontrada nos movimentos operários, políticos-ideológicos.

Entretanto, tudo indica que não houve repercussão nas publicações fora do grupo militante, pois a colônia italiana em Porto Alegre obteve, em geral, condições razoáveis de trabalho, isto é, como pequenos e médios proprietários.

Os imigrantes italianos, particularmente os que se estabeleceram em Porto Alegre, perseguiam, como os imigrantes em geral, o objetivo de alcançar fortuna. Tal objetivo, em certa medida, foi sendo alcança- 
do, quando se tornavam pequenos e médios proprietários, quase sempre, patrões de si mesmos.

\section{CONSIDERAÇÕES FINAIS}

A emigração italiana foi um fenômeno de massa que ocorreu como uma das conseqüências da penetração do capitalismo na Itália. $\mathrm{O}$ ato de emigrar, para muitos, foi uma forma de reação ao processo de proletarização; para outros, foi uma oportunidade para alcançar a posse da terra. Com o movimento emigratório italiano vastos contingentes se distribuíram em diversos países. O Brasil começa a receber grande fluxo desses emigrantes, principalmente a partir de 1875 .

Em Porto Alegre, os imigrantes italianos representaram, no período estudado, aproximadamente $10 \%$ da população, e deste total predominaram os italianos de origem meridional. Inseridos num processo de urbanização e modernização da cidade, eles criaram alguns espaços próprios de atividades coletivas, tais como associações, clubes, escolas, jornais etc. Fundaram também diversas sociedades italianas de mútuo socorro, para atender às necessidades de uma parcela destes imigrantes.

Os imigrantes italianos exerceram diversas atividades, alcançando, muitos deles estabilidade econômica, trabalhando no setor de prestação de serviços, normalmente como autônomos, ou no pequeno comércio, o que possibilitou na conjuntura local uma ascensão social.

Significativa foi a participação em atividades comerciais, predominando no pequeno comércio, e no médio comércio, baseando-se, em muitos casos, na mão-de-obra familiar.

As atividades de natureza industrial exercidas por italianos em Porto Alegre, em sua maior parte, foram modestas. Fábricas de pequeno porte, praticamente artesanais, com um número reduzido de operários e com pouca utilização de força motriz. Entretanto, em alguns ramos como o de alimentos, os imigrantes italianos detinham a maior parte da produção. Não foi verificada incidência numericamente expressiva de italianos trabalhando como operários nas indústrias.

Politicamente, o discurso positivista do PRR se adequou perfeitamente ao ideal de trabalho dos imigrantes italianos, que de fato ascenderam socialmente pela qualificação da mão-de-obra e, em alguns casos, associaram sua especialização ao capital de terceiros. 
A atividade produtiva dos italianos, prestando serviços, exercendo atividades em seu pequeno ou médio negócio, no comércio ou em suas fabriquetas, se apoiou sobremaneira na estrutura familiar, buscando sempre serem patrões de si mesmos, relacionando-se e identificando-se conforme sua posição social.

Os militantes italianos se restringiram a um pequeno grupo que atuava ao mesmo tempo em mais de uma associação operária, na imprensa, enfim em todos os movimentos e congressos operários do período. Num primeiro momento este fato leva à conclusão de um percentual mais elevado de imigrantes italianos entre sindicalistas.

Nas greves ocorridas, especialmente na de 1917, é que se verificou um expressivo número de italianos, mas ao lado do capital; são proprietários que atendem ou não às reivindicações de operários. Como a base do trabalho italiano era familiar, com pequeno número de empregados, muitos proprietários entravam diretamente em acordo; excepcionalmente, algum proprietário italiano tinha acima de vinte empregados, sendo então obrigado ou não a ceder após movimentos paredistas registrados em seus estabelecimentos.

Nos casos em que é referida a presença de operários italianos não militantes, estes apareceram na categoria de "fura-greves", como foi visto quando operários canteiros italianos foram mortos pelos colegas grevistas por não terem aderido ao movimento.

A imprensa operária italiana tentou aglutinar o suposto grupo operário italiano em Porto Alegre; entretanto, tudo indica que não obteve repercussão a propaganda política ideológica veiculada nestes periódicos, fora ou além do grupo militante.

Todos os indícios sugerem que os imigrantes italianos estabelecidos em Porto Alegre, em geral, ascenderam socialmente; corresponderam ao ideal positivista de trabalho e, fundamentalmente, conquistaram o objetivo primeiro de se tornar proprietários, mesmo que pequenos. Com o alcance gradativo desse objetivo, evidente reivindicação capitalista, seria impossível, como foi, surtir efeito a propaganda e o engajamento destes imigrantes em movimentos operários. O processo de ascensão e estabilidade atingido pelos imigrantes italianos em Porto Alegre e a conseqüente não-proletarização dos mesmos foi o maior entrave para a penetração e proliferação de ideais socialistas ou anarquistas no seio do grupo aqui estabelecido. Por outro lado, aqueles imigrantes nảo-envolvidos por tal processo, tudo indica, permaneceram na busca incessante do sonho da propriedade sem, porém, en- 
volverem-se politicamente; seguiram fielmente a doutrina do trabalho tão propagandeada pelos governantes positivistas.

Finalmente, pode-se afirmar que os imigrantes italianos não participaram de modo significativo dos movimentos operários em Porto Alegre.

A partir deste trabalho será possível aprofundar análises sobre a participação qualitativa de operários italianos no movimento operário de Porto Alegre, sua relação com outros grupos étnicos mais expressivos, analisar em que medida a influência ideológica trazida da Itália colaborou para o movimento como um todo, perceber a questão cultural etc. Os especialistas em movimento operário poderão buscar aqui dados significativos para suas pesquisas.

\section{Bibliografia}

BORGES, Stella. Italianos: Porto Alegre e Trabalho. Porto Alegre: EST , 1993.

BORGES, Stella \& COSTA, Rovílio. "Do sonho à Realidade: criminosos e doentes mentais alienados em Porto Alegre". In: DE BONI, Luis A. (org.). A Presença Italiana no Brasil (III). Porto Alegre/Torino: EST/Fondazione Giovanni Agnelli, 1996, p. 406-423.

CARONE, Edgar. Movimento operário no Brasil (1877-1944). São Paulo: Difel, 1984.

CENNI, Franco. Italianos no Brasil. São Paulo: Martins/EDUSP, 1975.

FAUSTO, Bóris. Trabalho urbano e conflito social (1890-1920). São Paulo: Difel, 1977.

FERREIRA, Maria Nazareth. A imprensa operária no Brasil, 1880-1920. Petrópolis: Vozes, 1978.

GARCIA, Evaldo da Silva. "A imprensa operária socialista brasileira do Século XIX”. Revista Estudos Sociais, n. 19, fev. 1964.

HARDMAN, Francisco Foot. Nem pátria, nem patrăo (Vida operária e cultura anarquista no Brasil). São Paulo: Brasiliense, 1984.

HARDMAN, Francisco Foot. História da indústria e do trabalho no Brasil. São Paulo: Global, 1982.

KLIEMANN, Luiza. "1917: Convergência de interesses, Governo Autoritário e Movimentos Operários". Estudos Ibero-Americanos, Porto Alegre: dez. 1980.

MARAN, Sheldon Leslie. Anarquistas, imigrantes e o movimento operário Brasileiro (1890-1920). Rio de Janeiro: Paz e Terra, 1979.

Revista Sul. Porto Alegre: s/d.

MARÇAL. Memória histórica dos socialistas gaúchos. S/l, s/d.

MARÇAL, João B. Primeiras lutas operárias no Rio Grando do Sul. Porto Alegre: Mercado Aberto, 1985. 
PETERSEN, Sílvia. "As greves no Rio Grande do Sul 1890-1919)" In: DACANAL, José Hildebrando (org.). RS: economia e política. Porto Alegre: Mercado Aberto, 1979.

PETERSEN, Sílvia. Origens do $1^{2}$ de Maio no Brasil. Porto Alegre: Ed. Univ./UFGRS, 1981.

PETERSEN, Sílvia. Guia para o estudo da imprensa periódica dos trabalhadores do Rio Grande do Sul (1874-1940). Porto Alegre: Ed. Univ./UFRGS/FAPERGS, 1989.

RODRIGUES, Edgar. Os anarquistas. Trabalhadores italianos no Brasil. São Paulo: Global, 1984.

RODRIGUES, Edgar. Socialismo e sindicalismo no Brasil. Rio de Janeiro: Laemmert, 1969.

TRENTO, Angelo. Do outro lado do Atlântico. São Paulo: Nobel, 1989. 